\title{
URBAN POVERTY ALLEVIATION STRATEGIES FROM MULTI- DIMENSIONAL AND MULTI-ETHNIC PERSPECTIVES: EVIDENCES FROM MALAYSIA
}

\section{Khoo Suet Leng*, Mohamad Shaharudin Samsurijan, Parthiban S. Gopal, Nor Malina Malek and Zahri Hamat}

Development Planning and Management Programme, School of Social Sciences, Universiti Sains Malaysia, Pulau Pinang, MALAYSIA

"Corresponding author: khoosuetleng@gmail.com

Published online: 28 September 2018

To cite this article: Khoo, S. L., Mohamad Shaharudin Samsurijan, P. S. Gopal, Nor Malina Malek and Zahri Hamat. 2018. Urban poverty alleviation strategies from multi-dimensional and multi-ethnic perspectives: Evidences from Malaysia. Kajian Malaysia 36(2): 43-68. https://doi.org/10.21315/ $\mathrm{km} 2018.36 .2 .3$

To link to this article: https://doi.org/10.21315/km2018.36.2.3

\begin{abstract}
Lately, poverty has been a highly contested concept. Traditionally, poverty was a phenomenon associated to those entrapped in the lower rungs of society. This perception is attributable to the quantitative measurement of poverty determined by a controversial indicator - the "poverty line". Historically, majority of the poor are rural folks with income levels below the poverty line. Massive ruralurban migration necessitated by industrialisation and rapid urbanisation caused the emergence of a new social class - the "new poor" or "urban poor". Though scholars argued that industrialisation and urbanisation do create opportunities for wealth accumulation, but at the opposite end of the continuum we now face the "urban poor" issue inflicting our urban citizenry. The dire situation demands that the poverty concept should go beyond income levels and be more all-encompassing and multi-dimensional. In Malaysia, the situation becomes more pressing because the Malaysian population comprises people from diverse ethnicities like Malays, Chinese and Indians as the three most dominant ethnic groups. Such ethnic diversity in Malaysia's social structure will reflect the way diverse socio-cultural and economic conditions shape and define poverty. Thus, due considerations should also be given to "ethnicity" when deliberating the strategies that can enable a person to escape the poverty cycle. This qualitative study attempts to fill a pertinent research gap by examining poverty alleviation strategies not only from a multi-dimensional approach, but also from Malaysia's multi-ethnic viewpoint.
\end{abstract}


This study highlighted that the receipt of aid/assistance differs amongst ethnic groups with Malays indicating more instances of receiving aid from the government compared to those of their Chinese and Indian counterparts. It was also found that the Chinese and Indians who escaped urban poverty depended mostly on personal values (i.e. diligence, perseverance, spiritual belief, self-discipline) to help them confront poverty. The recommendations from this paper will serve to reconceptualise the meaning of urban poverty in Malaysia and subsequently understand the different types of poverty alleviation strategies that are unique to each different ethnic group.

Keywords: Urban poverty, poverty alleviation strategies, Malaysia, developing country

\section{INTRODUCTION}

In development discourse, the concept of poverty has morphed and expanded beyond its original form. From a rudimentary concept that was purely based on income levels and poverty lines, the poverty concept has transformed to adopt a multi-dimensional approach with due consideration given to non-income dimensions such as health, education, housing and such (Callander, Schofield and Shrestha, 2012).

In the Malaysian context, national strategic plans such as the recent 11th Malaysia Plan saw initiatives and endeavours that adopted this multi-dimensional poverty concept (Government of Malaysia, 2015: 3-23). Although a commendable effort by the Malaysian Government, but at this point in time, actual adoption of this concept is still at its infancy. Thus, the poverty scenario in Malaysia up till now is largely measured and understood based on absolute poverty and relative poverty which are subsumed under the income-based poverty definition (Mohamed Saladin et al., 2011: 73).

Clearly, the concept of poverty is at a crossroads where efforts have to go towards truly comprehending poverty and contextualising it within the broader context of development which encompasses multi-dimensional approaches instead of uni-dimensional ones. The time has come for scholars and policy-makers to revisit, redefine and also reconceptualise the concept of poverty where it is no longer confined to the vagaries of rural citizenry because poverty has inflicted the urban milieu as seen in studies on urban development and urban poverty in Malaysia (Siwar and Mohd. Yusof, 1997; Elhadary and Narimah, 2012: 212). This is of utmost importance because until and unless a more relevant conceptualisation of poverty is understood, it would be a great challenge to formulate the correct types of poverty alleviation strategies to reach out to the target audiences. In Malaysia 
particularly, the situation becomes doubly challenging when the Malaysian citizenry comprises people from diverse ethnicities with Malays, Chinese and Indians being the three most dominant ethnic groups in the country. Such ethnic diversity in the Malaysian social structure will in turn reveal the way different socio-cultural and economic conditions tend to shape and define poverty. In this regard, due considerations should also be given to ethnicity when deliberating on strategies that can help a person escape from the vicious cycle of poverty.

Given that most Malaysian poverty studies have focused on the incomebased poverty definition (Mohamed Saladin et al., 2011: 73), there exists a research gap in conducting studies that look beyond this definition. Hence, this study attempts to fill this research gap by looking at poverty alleviation strategies not only from a multi-dimensional approach, but a multi-ethnicity perspective with regard to those who have broken the chain of poverty. The relevance of studying those who have escaped the poverty chain is more insightful and has farreaching implications for all stakeholders (Gopal and Nor Malina, 2015: 34). More specifically, this paper raises the following research question: What are the novel urban poverty alleviation strategies for the poor who have broken the poverty cycle featured from the multidimensional and multi-ethnic perspectives? The nature of this study and the way the research question is framed are of key significance to a developing and highly urbanised multi-ethnic country like Malaysia. This study is also timely and in line with contemporary development discourse and global visions such as the Sustainable Development Goals where Goal 1 succintly advocates for "no poverty" and to "end poverty in all its forms everywhere". The findings will contribute towards reconceptualising the concepts related to poverty and further comprehending the different types of poverty alleviation strategies that are unique to each ethnic group in Malaysia.

In an overview, this paper is organised into five main sections. Section 1 provides an introduction to the paper. Subsequently, Section 2 reviews key literature that is related to development and poverty. The various types of poverty alleviation strategies and policies are also highlighted here. A brief methodology will be outlined in Section 3 before discussing the key findings in Section 4 . Section 5 concludes the paper by suggesting possibilities and recommendations to redefine and reconceptualise the meaning of poverty and poverty alleviation strategies in Malaysia. 


\section{LITERATURE REVIEW}

\section{Understanding Poverty Within Development}

Before delving into the concept of poverty, it is important to first understand the meaning of development. Over the decades, development has morphed and evolved to be a fluid concept that is confusing and widely contested (Peet and Hartwick, 2009: 1). From a longitudinal sense, the meaning of development has morphed over time by adopting and adapting to different meanings and diverse connotations based on the development paradigm of a particular era. Historically, development used to emphasise quantifiable growth with attention given to a nation's economic growth. The focus at that time was to ensure that a nation was able to increase its output at a faster rate than its population growth (Todaro and Smith, 2011: 14). At that point, development was connoted as being a fully "economic affair" with an idealistic presumption that surpluses and per capita GNI growth are believed to flow downwards to the masses manifested through creation of employment and other economic opportunities. Development, at that juncture, rarely touched on issues related to poverty, inequality, social justice, rights, discrimination and marginalisation. However, during the $50 \mathrm{~s}$ and $60 \mathrm{~s}$ such material growth failed to make lives better, and worse still, the broader society started to manifest problems in the form of poverty, inequality, disparity and unemployment. It then triggered a dire need to relook and reconceptualise the meaning of development. As succinctly highlighted by Dudley Seers (quoted in Todaro and Smith, 2011: 15):

The questions to ask about a country's development are therefore: What has been happening to poverty? What has been happening to unemployment? What has been happening to inequality? If all three of these have declined from high levels, then beyond doubt this has been a period of development for the country concerned. If one or two of these central problems have been growing worse, especially if all three have, it would be strange to call the result "development" even if per capital income doubled.

No doubt, a nation cannot claim to be fully developed when its society is inflicted with issues related to poverty, unemployment and inequality. When these issues worsen with no clear solution in sight, it will inevitably affect other aspects of a person's life such as the ability to fulfil their basic needs as well as other related living requirements and demands in a modern world. Going deeper into the meaning of development, when one is deprived from enjoying even the basic needs, it will inherently lead to other forms of deprivation such as the inability to acquire decent housing, education etc. This is because the concept of poverty is no longer uni-dimensional in nature where monetary aspects are the 
main focus (van der Berg, 2008: 1). Over the decades, the concept of poverty has also morphed to be multi-faceted and multi-dimensional in nature by taking into consideration non-material and non-monetary dimensions (Callander, Schofield and Shrestha, 2012). The redefinition and expansion of the poverty concept into various dimensions (i.e. income, education, housing) is cognisant of the way development has been accorded a more holistic and all-encompassing notion in contemporary development literature. Arguably, by reconceptualising poverty from a multi-dimensional viewpoint, it will also broaden our understanding about issues related to inequality of income or asset distribution, especially in a multiethnic society like Malaysia where inequality amongst ethnic groups has been rampant and widely debated since independence. Therefore, the novelty of this paper lies in the framing of the analytical framework from multi-dimensional and multi-ethnic perspectives.

To date, poverty is a very wide concept with multiple definitions. Broadly, the two commonly used concepts of poverty are absolute poverty and relative poverty. "Absolute poverty" is gauged by the monetary resources required to fulfil basic needs like food, shelter and clothing (van der Berg, 2008: 1). But this concept fails to look at issues that are related to quality of life or the general levels of inequality in a society. Diverging from pure economics that conceptualise poverty by merely looking at quantitative indicators, for instance a country's poverty line, thus the emergence of the concept of "relative poverty" is welcomed and highly relevant to fulfil and address the social and cultural needs of individuals as well as to comprehend the incidences of inequality in a society. Hence, relative poverty is understood as poverty when compared to the socio-economic status of other members of the society. Essentially, relative poverty is a type of poverty determined by the society where a person resides (van der Berg, 2008: 10). For instance, a person is taken as being poor if he/she leads a life below current living standards in a particular context or circumstance of a society (UNESCO, n.d.). Having said that, even relative poverty is borne as an upshot of income indicators such as Gini coefficient. Hence, scholars argue that current measures of poverty which are based on income provide a murky insight on the well-being of the poor (Galer, 2012). This income rate is a poverty line which is a threshold below which families or individuals are considered to be lacking the resources to meet the basic needs for healthy living; in other words, having insufficient income to provide food, shelter and clothing needed to preserve health. On the contrary, they suggested that a rate based on consumption instead of income would provide more insight on the well-being of the poor. By the same token, Nair (2010) stated that even in Malaysia the official poverty rate which is income-based does not gauge the extent of poverty as well as a method based on real purchasing ability. This is because correctly calculating deprivation helps identify the most disadvantaged individuals and tracks changes over time. The methods for calculating the current 
poverty measurement remain largely unchanged and have been criticised by many researchers.

In Malaysia, poverty has traditionally been measured in one dimension, specifically income by using a poverty line income (PLI) to demarcate poor and non-poor households. The various changes that have occurred in the definition and measurement of poverty have important implications for the magnitude of the problem of poverty in Malaysia. Despite impressive improvements arising from various changes that have occurred in the definitions, concepts, measurement of poverty and reductions in the incidences of poverty between 1970-2014 $(49.3 \%-0.6 \%)$, there is some concern as to what this reduction means in real terms. Incidentally, the current approach in Malaysia still suffers from a number of weaknesses and is inadequate to truly reflect the poverty situation in the country (Roslan, 2004). The use of the PLI which is predominantly based on income factor to demarcate poverty groups from others in society is subject to numerous criticisms. The use of income alone as a proxy for describing human welfare is limited in light of the multifaceted nature of poverty dimensions, especially in urban areas (Sen, 1997; Shireen, 1998). Hence, the PLI fails to take into account variations in living costs within regions and the effects of variations in household size on poverty status are ignored (United Nations Development Programme [UNDP], 2008). It has been pointed out that the poverty line income should be updated to reflect changes in the costs of specific items (that make up the poverty line income) rather than adjust the poverty line income with Consumer Price Index as relative weights of these items (UNDP, 2008). In view of this contention, Galer (2012) asserted that consumption-based measurement better captures the most disadvantaged families compared to those based on income because it accounts for usage of savings, ownership of durable goods, access to credit and the use of antipoverty programmes. Furthermore, the most disadvantaged families also appear to report their consumption more accurately than income.

Additionally, experts distinguish between two types of poverty: exogenous poverty and endogenous poverty. Exogenous poverty in a population is initially caused by external factors. This may happen, for example, if resource exploitation ruins local livelihoods and the local population does not share in the proceeds such as in cases where the exploitation of mineral resources in a context of irresponsible governance may cause exogenous poverty. Similarly, the various global economic shocks invariably led to unemployment, especially among the bottom $40 \%$ (B40) of Malaysia's population. Eventually, unpredictable such changes caused them to be trapped in the cycle of poverty.

Although Malaysia was hit by the Global Financial Crisis in 2009 and recovered rapidly by posting growth rates averaging $5.7 \%$ since 2010 , the government is still committed towards enhancing the well-being of the poorest $40 \%$ of the population (the B40). This low-income group remains particularly 
vulnerable to the exogenous factor of economic shocks as well as increases in the cost of living and mounting financial obligations. The Global Financial Crisis of 2008-2009, with its epicentre in the United States, has brought enormous ramifications for the world economy including Malaysian economy. What started as an asset bubble caused by an array of financial derivatives that, inter alia, drove the sub-prime mortgage boom exploded into a housing and banking crisis with a cascading effect on consumer and investment demands. From a housing crisis, it quickly grew into a banking crisis with investment and merchant banks first absorbing the impact before it spread to commercial banks (Krugman, 2009). With America's economy contracting sharply, it sent ripples across export-dependent Asian economies which began to face a contraction as a consequence. Hence, although the Malaysian economy was insulated from the direct effects of financial exposure, the global financial crisis has cast doubt on the Government's plans to achieve vision 2020 due to a collapse in exports and slowdown in foreign direct investment (FDI).

Given Malaysia's high export to Gross Domestic Product (GDP) ratio, the contraction in external demand is the most serious factor burdening the economy. One direct source of problem comes from a contraction in export demand, particularly in manufacturing, as the target markets are primarily developed economies that are currently gripped by recession. A second direct source is a contraction in FDI inflows, particularly from these developed countries. The indirect sources of contraction came from all sectors dependent on GDP growth - consumer and investment demand - that affect agriculture, construction and services. Falling demand has already driven firms to retrench workers. Although reported retrenchments from government sources are small, it is believed that both underemployment (and with it the consequent fall in incomes) and unemployment figures are much higher than those officially reported.

On the other hand, endogenous poverty as caused by the population itself often follows on from externally induced (exogenous) poverty. Thus, this premise basically focuses on the individual as being responsible for his/her poverty situation. According to Parthiban (2013), typically, political conservative theoreticians blame individuals in poverty for creating their own problems and argue that with harder working attitude and better choices the poor could have avoided (and now can remedy) their problems. By extension, this literature implies that those who do not succeed economically or improve their well-being must face the fact that they themselves are responsible for their failure. More often than, not most of these poor are deemed lazy and are suffering from dependency syndrome. Endogenous factor of poverty is also caused by corruption in Malaysia. Most countries experiencing chronic poverty are seen as natural breeding grounds for systemic corruption due to social and income inequalities and perverse economic incentives. This segment further summarises the relationship between 
poverty and corruption to clarify the ways in which these phenomena interact. In countries where corruption is successfully controlled, there is greater inflow of foreign investments, higher per capita income growth, higher literacy rate and increased business growth (Kaufman, Kraay, and Zaido-Lobaton, 2000; quoted in Nik Rosnah, 2008). Hence, eradicating corruption in Malaysia inevitably helps in poverty alleviation to economic development.

Extending from the above poverty concepts and given the all-encompassing nature of contemporary development concept, the shift towards redefining poverty from a monetary or income approach to a multidimensional poverty measurement index is vital and also relevant for developing countries like Malaysia (Mohamed Saladin et al., 2011: 73). The dire need to revisit the poverty concept is evident when poverty is now increasingly an urban issue, thus, the emergence of the "new poor" categorisation or better known as the "urban poor". In 2014, the average monthly PLI was RM930 for Peninsular Malaysia, RM1,170 for Sabah and RM990 for Sarawak. As for urban poverty, the PLI was set at RM960 for Peninsular Malaysia, RM1,180 for Sabah and Wilayah Persekutuan Labuan, and RM1,020 for Sarawak as per Household Income Survey (HIS) 2016 (Economic Planning Unit, 2018). In the context of our study, this PLI was used to determine the samples of urban poor in both states. These people fall short of certain standards of consumption which are deemed necessary to maintain "decency" in society, for example, those who cannot afford healthcare and education (Idris, 2015). Urban poverty may occur when the urban household income falls below the poverty line even though family members are involved in paid employment. However, a highly paid worker who has to support a sizeable number of dependents may still be considered to be living in poverty if their income is slightly higher than the threshold of poverty line income, from the multidimensional perspective. Coupled with the rising cost of living in cities, there would naturally be a reduction in expenditures per capita a day, given a fixed amount of household income. The following section will review poverty in Malaysia and related poverty alleviation strategies in Malaysian cities.

\section{Poverty Alleviation Strategies in Malaysian Cities}

\section{Poverty in Malaysia}

In the early stages after Malaysia achieved independence, the percentage of Malaysians living below the poverty line was $70 \%$. This condition was worrying as this group of people had always been ignored, thus, causing "social exclusion" to happen (Mohd Ayop, 2013). A lack of focus and ineffective strategies during formulation of poverty alleviation programmes caused the inability of poor inhabitants in rural areas and cities to reap the benefits of the programmes (Mohammad Shatar, 2003; Mohd Ayop, 2013; Siti Hadijah, Roslan and Siti Norliza, 
2012). This condition encouraged the Malaysian government to pay considerable attention to reduce the percentage of poverty, especially after the race riots of 13 May 1969. The main factor that triggered this incident was a significant poverty gap between bumiputeras and non-bumiputeras. As a result, our government decided to introduce a policy called the New Economic Policy, NEP (1970-1990) with the aim to reduce the poverty gap between the different ethnic groups.

This effort not only reduced the poverty level of our nation, but at the same time it restructured the society and also consolidated unity amongst Malaysians. In 2014, Malaysia had successfully reduced the percentage of the population falling below the poverty line by $0.6 \%$ (included Sarawak and Sabah) (Mohd Ayop, 2013; Siti Hadijah, Roslan and Siti Norliza, 2012; Economic Planning Unit, 2016). In 2016, the percentage of Malaysians that had a monthly income of between RM2,500 to RM3,999 had increased to $23.9 \%$ as compared to $13.1 \%$ in 1995 (Economic Planning Unit, 2016). This achievement is parallel to the 10th Malaysia Plan (2010-2015) that targeted to increase the average monthly income of the lowest $40 \%$ of households known as B40 from RM1,440 in the year 2009 to RM2,300.

\section{The model of urban poverty alleviation}

The model of urban poverty alleviation is a part of the overall strategic framework and its main focus is on the urban poor as shown in Figure 1. Previous studies undertaken by Cling, Razafindrakoto and Roubaud (2002); Mohammad Shatar (2003); Abdul Saboor, Maria and Atta (2015) discovered that the poverty alleviation model that can successfully change the lives of the target population, especially those poverty groups in urban areas, can be divided into two categories i.e., financial oriented model and non-financial oriented model. However, these categories still focus on four forms of popular programmes for instance, (1) financial programme; (2) business premises provision; (3) products provision; (4) courses, skills training and community development (Abdul Saboor, Maria and Atta, 2015; Mohammad Shatar, 2003; Huafeng, 2014). Most of the models of poverty alleviation will be accompanied by a particular programme that is more focused on the micro objective and scope. However, what we need to consider is that all models are bounded with the compatibility of supporting factors, requirements and forms of assistance, the ability of the target group, the planning of stakeholders as well as government policies. According to Cling, Razafindrakoto and Roubaud (2002), the innovation model on poverty alleviation plays an important role and it includes the main objective, instruments, handling of debt, preparation of decision making, taking into account the strengths and weaknesses of the country and also the funding aspect. The following section will describe the four forms of popular poverty alleviation programmes. 
Khoo Suet Leng et al.

\begin{tabular}{|c|c|c|c|}
\hline Main Objective & Structural Adjustment & Poverty Reduction Strategy & New Principal \\
\hline$\underline{\text { Instruments }}$ & $\begin{array}{l}\text { - Economy policy } \\
\text { - Country Assisstance Strategy } \\
\text { - Enhance structural } \\
\text { adjustment facility }\end{array}$ & $\begin{array}{l}\text { - Poverty reduction support } \\
\text { credit } \\
\text { - Poverty reduction and } \\
\text { growth facility }\end{array}$ & $\begin{array}{l}\text { - Ownership } \\
\text { - Participation } \\
\text { - Donor Coordination }\end{array}$ \\
\hline$\underline{\text { Handling of Dept }}$ & - Indirect (NGOs, Agencies) & - Debt alleviation & \\
\hline Preparation & $\begin{array}{l}\text { - Top down decisions } \\
\text { - Policies impose from the } \\
\text { outside }\end{array}$ & $\begin{array}{l}\text { - National prepared policies } \\
\text { - Bottom up approach }\end{array}$ & $\begin{array}{l}\text { - Ownership } \\
\text { - Participation }\end{array}$ \\
\hline $\begin{array}{l}\text { Accounting for country } \\
\text { specificity }\end{array}$ & - Weak & - Strong & - Ownership \\
\hline Funding & - Project aid priority & - Budget support & $\begin{array}{l}\text { - Ownership } \\
\text { - Donor Coordination }\end{array}$ \\
\hline
\end{tabular}

Figure 1: Innovation model of poverty reduction brought by Poverty Reduction Strategy Papers (Cling, Razafindrakoto and Roubaud, 2002).

\section{Financial capital}

Financial capital is one of the crucial components in poverty alleviation programmes in urban areas. Normally, this concept is directed to community groups with entrepreneurship backgrounds such as hawkers and also petty traders. These communities are considered as poor groups in urban areas as they have always encountered the problem of lack of financial capital and also the challenge to obtain extra capital (Warr, 2004). Hence, this financial capital programme is being introduced in order to increase their ability to expand their businesses so that capital can be returned to the organising agency for distribution to other groups (Zahri, 2012). For example, the Selangor state government plays the role as organising agency to provide this type of financial support to businessmen or petty traders around major cities in Selangor to help them expand their businesses. A total of RM100 million had been assigned for this purpose. With the concept of "Deposit of Foundation Loan", this loan is being used as an extra capital in the business. Apart from the state government of Selangor, other government agencies such as Bank Negara Malaysia, Small and Medium Industries Development Corporation (SMIDEC), Tabung Ekonomi Kumpulan Usahawan Niaga/The National Entrepreneurial Economic Fund (TEKUN), Majlis Amanah Rakyat/ People's Trust Fund (MARA), Zakat institution and the ministries in the central government also used this supporting model to reduce the rate of poverty amongst petty traders and hawkers. 


\section{Business premises}

Aid in the form of business premises also form part of the poverty alleviation strategy in urban areas and it had been implemented in some South-East Asian countries such as Thailand, Laos, Vietnam and Cambodia. For instance in Vietnam and Thailand, the local government or the administrator of urban areas will ensure citizens, especially those with the ability and interest in business to have proper access to business premises. However, direct support in the form of providing business premises are rarely heard in Malaysia.

In Malaysia, business premises that are provided by local authorities to small businesses, hawkers and new entrepreneurs have their time limit. Normally, those business premises provided by local authorities will be rented out to small businesses with the lowest rental. The business premises that are rented out are bound by the business concept of the local authorities. For instance, the concepts introduced are like complexes for general businesses (clothes, foods and hawkers), complexes for farmers' market (fish and vegetables), and complexes for local products (craft products, traditional clothing and other Small and Medium-Sized Enterprises/Industri Kecil dan Sederhana [IKS]'s products). All these businessmen will be charged based on the contract that they have signed. Choice of business lot will be determined by the local authorities. Besides, the State Development Corporation of each and every state such as MARA and Lembaga Kemajuan Wilayah Pulau Pinang/Penang Regional Development Authority (PERDA) also played the same role in empowering the emergence of new entrepreneurs by encouraging them to rent and do business in those designated premises (MARA, 2016; PERDA, 2016; Perbadanan Kemajuan Negeri Selangor [PKNS], 2016).

\section{Goods and equipment}

Aid in the form of goods or equipment is one of the poverty alleviation model that has always been used in most developing countries. In Malaysia, these kinds of assistance are always provided by government agencies, private agencies as well as non-governmental organisations. Aid in the form of goods and equipment seem to be more focused on community groups based on their experiences, skills and abilities to use such equipment. For example, The Fisheries Development Authority of Malaysia (Lembaga Kemajuan Ikan Malaysia, LKIM) also supplied some fishing-related equipment such as fishing boats, fishing nets and boat engines as initial capital in order to improve Malaysian fishermen's ability to catch fish (Mohd Shaladdin, Wan Abdul Aziz and Nik Wan, 2006; Lembaga Kemajuan Ikan Malaysia [LKIM], 2016). Equipment such as lawnmowers, wood cutting machines, welding machines, generators, wind pressure machines and many more are some 
of the equipment aid that have been supplied to target poverty groups within the fishermen fraternity. The objective of this effort is to enable them (poverty group) to be more independent and self-employed (MARA, 2016; PERDA, 2016).

While aid in the form of goods such as product and packing are provided, there are a number of small and medium enterprises (SMEs) that provided such goods to target poverty groups who are interested without having to make any deposit with the respective SME. By doing so, these poor people can conduct small scale businesses and earn some revenues. In Thailand and Vietnam for example, most of the local craftsmen (either individually or cottage industry) will provide opportunity to small businesses to get their stock without any deposit (Warr, 2004; $\mathrm{Vu}$ Quac, Tran and Pung, 2012). Besides that, the Association of Businessmen also plays a pivotal role by giving priority to new entrepreneurs to obtain capital and product (Warr, 2004). This kind of assistance and support is very important to strengthen the ability of the urban poor to enjoy a better life.

\section{Courses, training and community development}

Courses and skills training, are some of the strategies suggested in the poverty alleviation model that are often used in most poverty alleviation programmes. In Malaysia, the government has spent millions of ringgit to ensure the poor, especially those in urban areas have a particular set of surviving skills. Skills programme and related courses that focus on various levels of society, ordinary residents, leaders, ladies, and youth are planned based on the specific goal(s) and focus (Abdul Saboor, Maria and Atta, 2015; Mohammad Shatar, 2003). A study by Huafeng (2014) showed that courses and training framework with specific educational modules are able to provide sustainable capacity for the poor, especially in urban areas. This is because the development of courses and training will have a direct impact towards strengthening human capital development in becoming more competitive and sustainable in the long run. The study is aligned with Mohammad Shatar's (2003) findings that emphasised courses, training and development of human capital as the most important component of the community development model which is able to eventually reduce poverty. Having understood the various strategies of poverty alleviation, the next section will outline the methodology for this study.

\section{METHODOLOGY}

The study of urban poverty is not new in Malaysia. Generally, previous studies were undertaken based on secondary data sources from the Economic Planning Unit and Department of Statistics (Siwar et al., 2016), conducted purely by ways 
of quantitative methods (Nurliyana, Zalmiyah, and Rohayanti, 2017) or even predominantly conceptual in nature (Nair, 2010). This study differs by studying urban poverty based on a mixed method approach that combines both quantitative and qualitative techniques. However, for the purpose of this paper and due to limitation of space, only the qualitative techniques and aspects will be discussed. For qualitative data collection, a semi-structured interview tool was used to elicit data. The semi-structured interview was undertaken upon completion of the quantitative component which involved a questionnaire survey that was conducted in both Pulau Pinang and Selangor. The interviewees for the subsequent semistructure interviews were selected from 300 respondents who participated in the earlier survey. After completing the questionnaire survey, 50 most appropriate respondents were selected as participants for the semi-structured interview in accordance with the conditions stipulated below. These respondents were from the three main ethnic groups: Malay, Chinese and Indian. The criteria of selecting the 50 participants (of the qualitative sample size) from the earlier survey respondents (of the quantitative data) are based on the respondents who had successfully formulated the most novel strategies to escape from the cycle of poverty vis-àvis their previous poverty state. Hence, these selected respondents were tested based on two different time dimensions, namely the first five years (2005-2010) of being trapped in the cycle of poverty and the subsequent five years (2011-2015) of having escaped from the poverty trap. In the first time frame (2005-2010), these respondents were either below the poverty line income of RM930 or the mean monthly income of RM6,311 whereas in the second time frame (2011-2015) they have either raised above the poverty line income of RM930 or the mean monthly income of RM6,311.

Among the key points of investigation in this research is to comprehend not only the meaning and causes of urban poverty from a multi-ethnic and multidimensional perspective but mainly on the participant's (interviewee's) approaches/ methods on breaking away from the poverty cycle. Thus, the viewpoints of the poor are considered and understood from a bottom-to-top approach. The interviews were conducted in the languages of the participants based on their respective mother tongues as this is a multi-ethnic study. The interviews were recorded upon consent from the interviewees. The interviews were then translated and transcribed. Each interview session took between 40 minutes to two hours. In analysing the interview transcriptions, the researchers concentrated on both the manifest content as well as latent content of the texts. Manifest content analysis entails what the texts says explicitly only, thus dealing largely on giving description of the visible and obvious components of the text (Oiler, 1982; Downewamboidt, 1992 quoted in Premalatha, 2005; Koch, 1995). On the contrary, latent content analysis requires the researcher to interpret the underlying meaning of the text (Draper, 1997 and Kondracki et al., 2002 as quoted in Premalatha, 2005). 
For the purpose of systematically evaluating the interview transcriptions, content analysis was used to make replicable and valid inferences by interpreting and coding textual material. In this regard, two methods of content analysis based on domain and semantic analyses were undertaken. Domain analysis was conducted by quantifying the qualitative data for frequencies and percentages. For example, the number of emerging themes pertaining strategies to alleviate urban poverty were tabulated for frequencies. Subsequently, semantic analysis was conducted by analysing the content of the statements in order to dissect, interpret and understand the deeper meaning of the issue under examination. Through nonparticipatory observation, the researchers also recorded notes on the field based on their observations about the respondents, their living or working conditions, well-being and so on. The field notes were used to complement and supplement the semi-structured qualitative data source.

\section{FINDINGS}

\section{Receipt of Assistance and Aid from a Multi-Ethnic Perspective}

When asked the type(s) of assistance or aid they received to facilitate their escape from the poverty chain, there are some significant differences between ethnic groups. A sizeable portion of the Malay interviewees disclosed that they received aid from the government and such aid is in one way or another seen as a poverty alleviation strategy for them. For instance, one Malay respondent mentioned that she received aid from the government when she related the following:

Lately, I received assistance from Federal Agricultural Marketing Authority, FAMA (a government agency). I also received financial assistance from Amanah Ikhtiar Malaysia (AIM). AIM allows us to roll with our capital. But for FAMA, they gave us equipment and electrical appliances for my business such as fridge, kitchen equipment, pots, and blender.

(Malay respondent No. 2, Pulau Pinang)

However, almost all of the Malay interviewees highlighted that the key poverty alleviation strategies depended solely on the individual. According to them, personal attributes such as a person's attitude (sikap) was of utmost importance. To alleviate poverty, the interviewees also opined that a person must be hardworking and not be lazy (malas). In addition to the above personal attributes and the availability of aid, all Malay interviewees were aware of the importance of 
education (pendidikan) as a pre-requisite to exit the poverty cycle. Although the interviewees themselves had low academic attainment, all of them were fully aware of the importance of education as a key strategy to alleviate poverty. As such, the interviewees strived hard to ensure that their off springs currently have access to a considerable level of education to avoid them from falling back into the cycle of poverty.

The scenario for Chinese and Indian respondents is significantly different from their Malay counterparts. Almost all of the Chinese and Indian respondents pointed out that they did not receive any forms of financial assistance or other material aid from the government or private sector. In fact, quite a number of the Chinese respondents lamented that they were not aware of the types of aid or programmes offered by the government. Only a small handful mentioned that they received the annual (Bantuan Rakyat 1Malaysia) BR1M from the government.

\section{Strategies to Alleviate Poverty from a Multi-Ethnic Perspective}

\section{Good personal attributes}

From the findings, respondents repeatedly highlighted good personal attributes such as being "hardworking", "disciplined", "punctual", and having "perseverance" and "self-determination" to shape a better future for a person. Interestingly, amongst the Indian respondents, non-material elements such as "spiritualism" was constantly mentioned and linked to the aforementioned attributes when they were asked how they could escape from poverty. The following statement on spirituality was mentioned by one of the Indian respondents when asked what forms of poverty alleviation strategy did he receive.

No, we did with our own attempts as we believe in the Tamil culture which says "Trust in your own hands and no one, except God."

(Indian respondent No. 5, Selangor)

The same was said by another Indian respondent as follows:

Yes, spirituality I am inclined as I believe in God and that God will make me successful. It is not the money, but discipline, determination, honesty, good attitude and all the positive characteristics that come through spirituality. 
Besides highlighting perseverance, the Chinese respondents mentioned that one has to be "frugal" to escape poverty. Most of the Chinese respondents mentioned it all depended on oneself and it was important to be "hard-working" and constantly find opportunities for oneself to earn extra given the high cost of living nowadays. For instance, one of the Chinese respondents highlighted the following:

Be hard-working and need to set a target for yourself. You need to choose the better path in order to have a better living.

(Chinese respondent No. 5, Selangor)

Similarly, another respondent also agreed that by being hardworking and exploring more job opportunities would be a viable strategy to alleviate poverty. Interestingly, this respondent also recommended that one should befriend and network with the rich in order to explore and obtain such opportunities. The following was said by the respondent:

Go out and find more opportunities and do more jobs. Get in contact with the rich in order to get such opportunities.

(Chinese respondent No. 7, Selangor)

The Indian respondents also echoed quite similar responses. When asked to highlight the types of poverty alleviation strategy, almost all of them mentioned about personal attributes as the key determinant to enable a person to come out from the poverty cycle. Many of the Indian respondents also highlighted the need to be prudent or even frugal in their daily expenditure and the need to "spend within their means" and spend predominantly on basic needs only. As succinctly highlighted by one of the Indian respondents:

We live within our means. No unnecessary expenditure. We spend only for the most important basic things.

(Indian respondent No. 9, Selangor)

The same strategy was mentioned by another Indian female respondent as follows:

I don't go for the unimportant things apart from the basic necessities of the family. 
This similar strategy was also echoed by another Indian respondent as stated below:

We lived within our means as what our parents did when we were children. Therefore, these are the factors that enabled us to go through.

(Indian respondent No. 6, Selangor)

A notable feature amongst the Indian community was the fact that almost all of the respondents do not eat out and prefer to cook their own meals at home in order to cut cost. One of the Indian respondents mentioned their eating patterns as follows:

We don't eat out at all. Only on my pay day that I'll take my children out to the nearest food court or buy back for them their favourite food.

(Indian respondent No. 5, Selangor)

\section{Education as a strategy to escape poverty}

Similar to Malay respondents, the Indian and Chinese respondents were all well aware of the importance of education and the need to sufficiently educate their children so that their future generation will be spared from being trapped in the vicious cycle of poverty. As surmised by one of the respondents pertaining the importance of education:

A lack of good formal and reasonable education is also a factor referring to poverty.

(Indian respondent No. 9, Selangor)

Similarly, another respondent also echoed the same thing.

Eat well and give ultimate importance to education.

(Indian respondent No. 3, Selangor)

Despite her status as a single mother, an Indian lady highlighted that it was her responsibility and obligation towards her daughter to provide her with good education. Her thoughts on this are stated follows: 
I deem it as my responsibility to give her the necessary education as I am very confident that education is the only means of survival at these times, especially for the Indian community that doesn't have many privileges or aid from any sources. Furthermore, with education she will be more daring to face challenges.

(Indian respondent No. 4, Selangor)

Similarly, a Chinese respondent in Kuala Lumpur also shared the same thoughts about education as a strategy to escape poverty. His thoughts are as follows:

I think the most important thing is to go and attend more training and to improve yourself to become more competitive. Besides that, we should study more, gain more certificates and the company will value you more.

(Chinese respondent No. 13, Selangor)

The following section attempts to understand the varying types of poverty alleviation programmes that recipients required and the contributing factors that shaped their needs.

\section{Poverty alleviation programmes from a multi-dimensional and multi-ethnic perspective}

The majority of respondents recognised that the form of relief programmes cannot be uniform as the needs of each recipient are different. As reviewed in the literature, a pluralistic society like Malaysia with diverse ethnic groups would have different needs and varying dimensions in addressing their respective poverty issues, especially when poverty has taken a multi-dimensional perspective now. Thus, the capability, mental strength and emotion of the recipients need to be considered in granting or designing poverty alleviation programmes so that the designed programme can achieve the objectives. Most of the respondents highlighted that assistance in the form of financial aid, product, courses or training are able to affect and make changes to the recipients. However, the kinds of assistance provided need to follow priority. First, self-readiness of the recipient group (recipient groups that have experience in conducting business or groups that fully depend on the business) followed by financial capital and product technology (target groups that have strong financial ability and technology as well as target groups with good marketing network). Third, motivational guidance and development of mental strength for the target group are also of utmost importance. 


\section{Self-readiness of recipient groups}

A majority of the respondents believed that the right forms of assistance should be provided to the right target group, i.e. those with prior experience in business, those fully dependent on business and also those with complete business capital assets. The specific assistance to recipient groups (as mentioned before) is considered as appropriate for achieving the objectives of the aid provided.

...this is what I said. They should only provide assistance to those who really want to conduct business. Sometimes, they tend to give assistance to those who are not interested in doing business. They keep on providing assistance and some of them (recipient) kept it (goods, equipment etc.) in their house. All this happened before my eyes...

\section{(Malay respondent No. 2, Pulau Pinang)}

A majority of respondents believed that the failure of donors to identify the right and appropriate group of beneficiaries resulted in the failure of the programmes. One of the reasons that caused this to happen is the lack of selfreadiness of recipient groups or sometimes the selected recipients are not experienced enough to carry out their own business. Indiscriminate assistance is given to them just because they are poor. As a result, they fail to operate their businesses. The following statement was made by one female Malay respondent.

...I think they shouldn't simply provide assistance. They (donor) should identify their recipients' needs before giving any help. If they are given inappropriate goods or equipment, they tend to sell them. Just give them what they need to conduct their business...

(Malay respondent No. 2, Pulau Pinang)

Most of the respondents also viewed the suitability of assistance through improvements in infrastructure. The right allocation towards improving infrastructures also plays an important role in improving self-readiness of the beneficiaries or recipient groups. For example, by means of upgrading basic infrastructures such as providing toilets, more comfortable retail spaces, water, electricity, visitors lounge and the like will boost the potential of a particular business location. This was pointed out by one of the respondents as follows:

...If the government is going to offer me assistance, I would like to upgrade all those infrastructures. This is a must. Try to build a business space with roof, so that we can do our business over there... 
(Malay respondent No. 1, Pulau Pinang)

\section{Financial capital and product technology}

Financial capital and product technology are the forms of assistance that were requested by most of the respondents. There is no doubt that the government has developed a variety of aid projects for financial capital and product technology. However, according to most of the respondents, there is still room for improvement towards this effort.

The government really helps us a lot. As I said before this, I hope the government can provide us with product technology that is easy for us to use and control. Currently I'm not using any machine. If I have a machine, it will definitely save my time...

(Malay respondent No. 3, Pulau Pinang)

The improvement in allocating this assistance is needed so that focus can be extended to the right and appropriate target groups by considering contributing factors such as experience and the physical capabilities of recipients such as having ownership of operational premise in producing the products. If no due consideration is given, the assistance provided might be misused or be abused. As purported by Mohd Shaladdin, Wan Abdul Aziz and Nik Wan (2006) in the literature review, the government's assistance in the form of essential goods that will facilitate the community's daily life and assist them towards generating more income play a crucial role. It can help them to improve their ability to remain competitive in a challenging and volatile environment.

Support in the form of financial capital and product technology seem to be more effective if the government tries to act as a mediator in forming or creating a joint venture with companies or individuals who are knowledgeable and experienced in the business. Direct support to this group is important to build their confidence and strengthen their capacity in producing the products. This condition can indirectly avoid any misuse of the assistance received. The importance of government support was also highlighted by one Indian respondent.

Yes, we plan to venture into a business... government support is necessary...

(Indian respondent No. 10, Selangor) 


\section{Motivation, guidance and development of mental strength}

Motivation, guidance and mental strength development were important in building and unleashing the existing potentials of respondents. A majority of respondents from all three ethnic groups acknowledged that a person's ability to escape the cycle of poverty is related to mental strength. As highlighted in the literature, mental strength through the application of motivational guidance on a regular basis was reflected as an effective instrument in promoting positive values amongst the participants (Mohd Shaladdin, Wan Abdul Aziz and Nik Wan, 2006).

...the government rarely organised motivational programmes for the poor. Maybe they (government) think that the motivational programmes might be useless to them (the poor). Actually, it's necessary to organise this kind of motivational programmes in order to unleash their potentials. This is what private agencies do. However, it's expensive and nobody could afford it...

(Malay respondent No.7, Pulau Pinang)

According to the respondents, motivational counselling programmes through the media (that links religion) have shown evidence that the application of positive values can result in changes. Such initiatives are seen as part of the key elements in driving changes amongst the poor, especially those in urban areas.

...what I discovered was, government put a lot of effort on it. For instance, motivational programme related to religion etc. are good enough. If the media especially TV or government can sustain this kind of programmes, I believe that all those urban poor can benefit from it and at the end can get away from hardship...

(Malay respondent No. 6, Selangor)

Figure 2 illustrates the poverty alleviation programmes from the respondents' perspectives after interviewing them. 


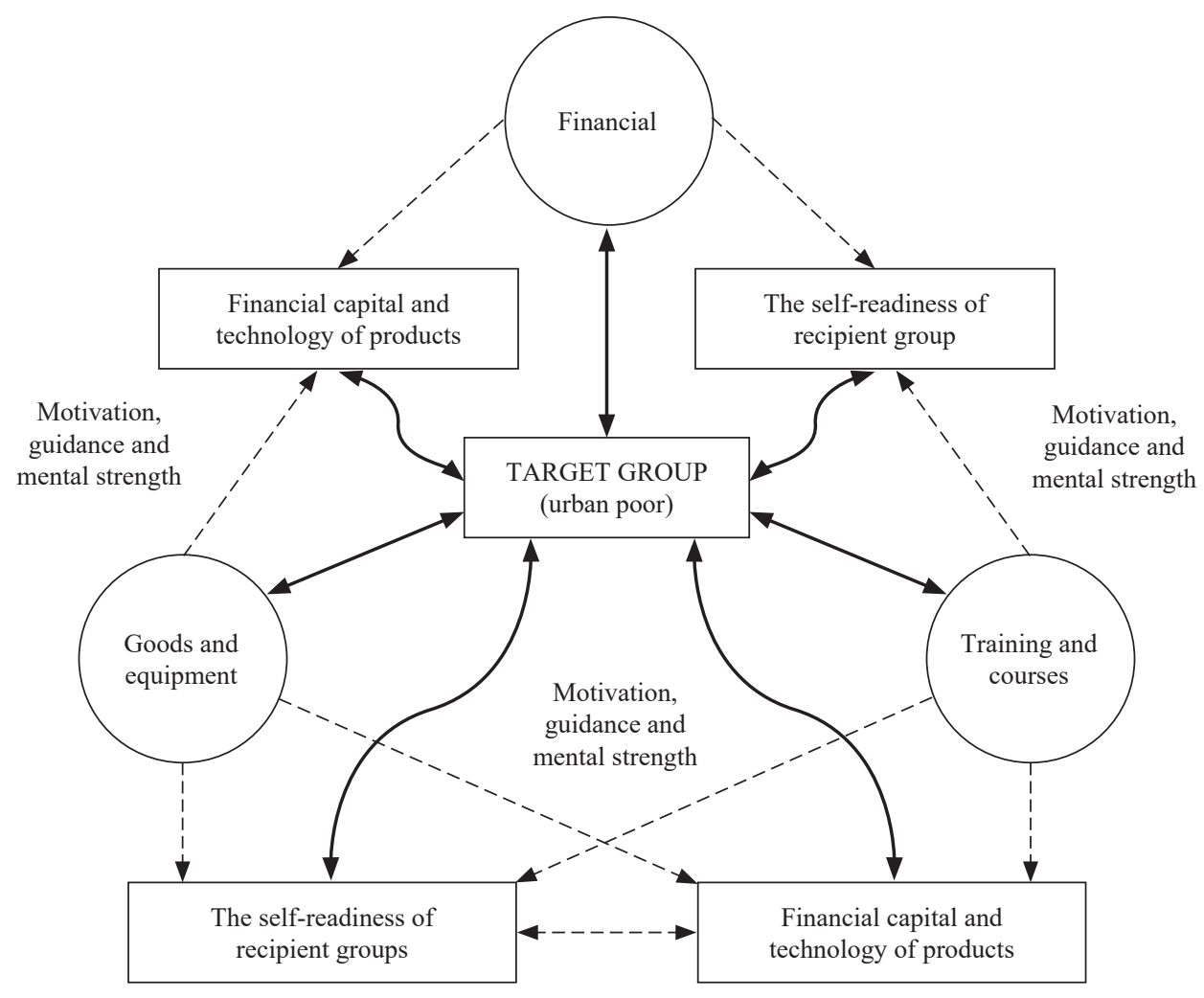

Figure 2: Poverty relief programmes through respondents' perspective.

\section{CONCLUSION}

No doubt, since political independence in 1957 until today, the Malaysian government has undertaken countless poverty alleviation strategies to combat poverty especially in rural areas. In the last decade, however, poverty issues have permeated into urban settings thus resulting in urban poverty which is the focus of this research. Given such spatial and contextual differences between urban and rural poverty, hence, the forms of poverty alleviation programmes angling from a multi-dimensional and multi-ethnic viewpoint as purported in this study is novel towards reconceptualising the plethora of urban poverty. Based on the way poverty has now been reconceptualised from multi-dimensional and multi-ethnic viewpoints, thus, this will implicate on the types of poverty alleviation strategies required for a multi-ethnic society like Malaysia where a growing number of the country's population is now residing in urban areas. 
From this study, it was illustrated that receipt of aid/assistance differs amongst ethnic groups with the Malays indicating more instances of receiving aid from the government compared to those of their Chinese and Indian counterparts. The Chinese and Indians who have escaped from urban poverty relied predominantly on personal values and discipline to help them confront poverty and related forms of material and non-material deprivations. Values such as diligence, perseverance and earnest spiritual beliefs were also some of the "strategies" mentioned. Good personal attributes mentioned in this study, however, were not part of the previous literature. Thus, possessing such attributes is indeed a novel way to alleviate poverty and is in line with the reduction of endogenous poverty by the individual themselves as elucidated by Parthiban (2013) in the above literature review.

In Malaysia, generally aid was given as a blanket strategy to those who are defined poor by PLI without first understanding their actual needs. It cannot be denied that different ethnic groups with different manifestations of poverty will require different poverty alleviation strategies and the dimensions deemed important to them will also be different and cannot be generalised across for all Malaysians. This is the flaw of the use of archaic poverty definitions that are uni-dimensional and tend to view society as a homogeneous entity without understanding the complexities within it. Such understanding of poverty becomes even more problematic for a pluralistic and multi-ethnic society like Malaysia.

In addition, this study also pointed out that the government should not extend aid/assistance to recipients in an indiscriminate manner without first understanding the actual needs of the recipients. Calls and actions towards more proper and accurate strategies to ensure that the correct forms of aid reach the right target groups are required. To this end, before providing anymore future aid/ assistance, a proper needs analysis and audit exercise with regard to the types of aid/assistance is recommended to be undertaken by the government given that poverty is no longer a straightforward quantitative measurement that delineates and ascertains a Malaysian as poor primarily due to his/her income levels. Now, considering the all-encompassing nature of poverty from a multi-dimensional perspective as well as taking into account Malaysia's multi-ethnicity, this study recommends that the concept of urban poverty in Malaysia should be revisited and extended. Lastly, poverty alleviation strategies should be needs-based and be tailored according to the particular needs of a certain ethnic group in relation to the dimension (i.e. housing, education, healthcare) that is deemed most pertinent to them. 


\section{ACKNOWLEDGEMENTS}

The authors would like to express their profound gratitude to the Research Creativity and Management Office (RCMO), Ministry of Education via Universiti Sains Malaysia for funding this project under the Fundamental Research Grant Schme (FRGS) No: 203/PSOSIAL/6711460.

\section{REFERENCES}

Abdul Saboor, Maria Manzoor and Atta Ullah Khan. 2015. Time use poverty and gender inequality: Empirical evidences from Punjab. Quality \& Quantity 50(1): 421438. https://doi.org/10.1007/s11135-014-0156-y

Callander, E. J., D. J. Schofield and R. N. Shrestha. 2012. Towards a holistic understanding of poverty: A new multidimensional measure of poverty for Australia. Health Sociology Review 21(2): 141-155. https://doi.org/10.5172/hesr.2012.21.2.141

Cling, J. P., M. Razafindrakoto and F. Roubaud. 2002. The PRSP initiative: Old wines in Newbottles? Europe Conference Paper, Oslo, Norway. 24-26 June.

Economic Planning Unit. 2018. The Malaysian economy in figures 2018. http://epu.gov. $\mathrm{my} / \mathrm{sites} /$ default/files/MEIF_2018.pdf (accessed 2 June 2018).

2016. The Malaysian economy in figures 2016. http://www.epu.gov.my/sites/ default/files/MEIF\%202016.pdf. (accessed 8 May 2017).

Elhadary, Y. A. E. and Narimah Samat. 2012. Political economy and urban poverty in the developing countries: Lessons learned from Sudan and Malaysia. Journal of Geography and Geology 4(1): 212-223. https://doi.org/10.5539/jgg.v4n1p212

Galer, S. 2012. New study finds consumption measures poverty better than income. https:// news.uchicago.edu/article/2012/08/17/new-study-finds-consumption-measurespoverty-better-income (accessed 9 November 2017).

Gopal, P. S. and Nor Malina Malek. 2015. Breaking away from the cycle of poverty: The case of Malaysian poor. The Social Science Journal 52: 34-39. https://doi. org/10.1016/j.soscij.2013.10.016

Government of Malaysia. 2015. Eleventh Malaysia Plan 2016-2020. Anchoring growth on people. Kuala Lumpur: Prime Minister's Department.

HIJRAH SELANGOR. 2016. Pinjaman asas simpanan. http://www.hijrahselangor.com/ (accessed 12 July 2016).

Huafeng, Z. 2014. The poverty trap of education: Education-poverty connections in Western China. International Journal of Educational Development 38: 47-58. https://doi.org/10.1016/j.ijedudev.2014.05.003

Idris Jala. 2015. The measure of poverty. http://etp.pemandu.gov.my/Transformation Unplugged-@-The_measure_of_poverty.aspx (accessed 13 November 2017).

Khan, A. U., A. Saboor, S. Ahmad and I. Ali. 2011. Mapping and measuring of multidimensional poverty in Pakistan: Empirical investigations in Pakistan. Journal of Life Social Sciences 9(2): 121-127. 
Koch, T. 1995. Interpretive approaches in nursing research: The influence of Husserl and Heidegger. Journal of Advanced Nursing 215: 827-836. https://doi.org/10.1046/ j.1365-2648.1995.21050827.x

Krugman, P. 2009. The return of depression economics and the crisis of 2008. New York: Norton.

Lembaga Kemajuan Ikan Malaysia (LKIM). 2016. Pembangunan masyarakat dan pertubuhan nelayan. http:/www.lkim.gov.my/pembangunan-masyarakat-danpertubuhan-nelayan/ (accessed 11 July 2016).

MARA. 2016. Makluman umum premis perniagaan. http://www.mara.gov.my/ (accessed 11 July 2016).

Mohamed Saladin Abdul Rasool, Mohd Fauzi Mohd Harun, Ariffin Mohd Salleh and Noraini Idris. 2011. Poverty measurement in Malaysia: A survey of the literature. Akademika 811: 73-81.

Mohammad Shatar Sabran. 2003. Model pembangunan komuniti. Pertanika Journal of Social Sciences \& Humanities 112: 135-145.

Mohd Ayop Abd Razid. 2013. Kejayaan Malaysia dalam program basmi kemiskinan. Putrajaya: Bahagian Penerbitan Dasar Negara, Kementerian Penerangan Komunikasi dan Kebudayaan.

Mohd Shaladdin Muda, Wan Abdul Aziz Wan Mohd Amin and Nik Wan Omar. 2006. Analisis kesejahteraan hidup nelayan pesisir. Jurnal Kemanusiaan 8: 58-77

Nair, S. 2010. Moving forward: Its poverty agenda challenges, dilemmas and options for Malaysia. Paper prepared for The Chronic Poverty Research Centre (CPRC) 2010 Conference, University of Manchester. 8-10 September.

Nik Rosnah Wan Abdullah. 2008. Eradicating corruption: The Malaysian experience. $J O A A G$ 3(1): 42-53.

Nurliyana Abd Manap, Zalmiyah Zakaria and Rohayanti Hassan. 2017. Investigation of poverty indicators for designing case representation to determine urban poverty. International Journal of Advances in Soft Computing and its Applications 9(2): 90-106.

Oiler, C. 1982. The phenomenological approach in nursing research. Nursing Research 313: 178-181. https://doi.org/10.1097/00006199-198205000-00013

Parthiban, S. G. 2013. Urban poverty among Indians in Penang: A study on nonmaterial causes. PhD diss., School of Social Sciences, Universiti Sains Malaysia, Pulau Pinang.

Peet, R. and E. Hartwick. 2009. Theories of development: Contentions, arguments, alternatives. 2nd ed. New York: The Guilford Press.

Perbadanan Kemajuan Negeri Selangor (PKNS). 2016. Pejabat maya. http://www.pkns. gov.my/my/aktiviti/pejabat-maya/ (accessed 11 July 2016).

PERDA. 2016. Business premises and small scales industry (IKS). http://www.perda.gov. my/index.php/en/maklumat-kami/program-pembangunan/premis-perniagaandan-iks (accessed 11 July 2016.)

Premalatha, K. 2005. Students' educational preferences and occupational aspirations. PhD diss., School of Social Sciences, Universiti Sains Malaysia, Pulau Pinang.

Ritchie, J. and J. Lewis. 2003. Qualitative research practice: A guide for social science students and researches. London: Sage Publications. 
Roslan, A. H. 2004. Measuring poverty in Malaysia: Applications of distributive-sensitive poverty indices. Malaysian Management Journal 8(1): 25-37.

Sen, A. 1997. On economic inequality: Expanded edition with a substantial annexe by James E. Foster \& Amartya Sen. Oxford: Clarendon Press.

Shireen Mardziah Hashim. 1998. Income inequality and poverty in Malaysia. Maryland, USA: Rowman \& Littlefield Publishers, Inc.

Siti Hadijah Che Mat, Roslan A. Hakim and Siti Norliza Jumali. 2012. Indeks kemiskinan pelbagai dimensi sebagai altenatif pengukuran kemiskinan. Prosiding PERKEM VII Jilid I: 181-191.

Siwar, C., F. Ahmed, A. Bashawir and M. S. Mia. 2016. Urbanization and urban poverty in Malaysia: Consequences and vulnerability. Journal of Applied Sciences 164: 154-160. https://doi.org/10.1108/03068299710193958

Siwar, C. and Mohd. Yusof Kasim. 1997. Urban development and urban poverty in Malaysia. International Journal of Social Economics 2412: 1524-1535.

Sulochana, N. 2010. Moving forward: Its poverty agenda challenges, dilemmas and options for Malaysia. Paper presented at the The Chronic Poverty Research Centre (CPRC) 2010 Conference, University of Manchester. 8-10 September.

Todaro, M. P. and S. C. Smith. 2011. Economic development. 11th ed. England: Pearson Education Limited.

United Nations Development Programme (UNDP). 2008. Malaysia measuring and monitoring poverty and inequality. Kuala Lumpur, Malaysia: UNDP.

United Nations Educational, Scientific and Cultural Organization (UNESCO). n.d. Poverty. http://www.unesco.org/new/en/social-and-human-sciences/themes/internationalmigration/glossary/poverty/ (accessed 18 March 2015).

Vu Quac Huy, Tran Hung and Pung Van Quan. 2012. Managing aid for trade and development results: Vietnam case study. 1-46. Paris, France and Vietnam: Organisation for Economic Co-operation and Development (OECD) and EU Viet Nam Office.

van der Berg, S. 2008. Poverty and education. Education policy series. Paris and Brussels: The International Institute for Education Planning IIEP and The International Academy of Education IAE.

Warr, P. 2004. Globalisation, growth and poverty reduction in Thailand. ASEANEconomic Bulletin 211: 1-18. https://doi.org/10.1355/AE21-1A

Zahri Hamat. 2012. Skim bantuan modal perniagaan di institusi zakat di Malaysia. http://www.zahrihamat.com/2012/11/skim-bantuan-modal-perniagaan-di.html (accessed 12 July 2016). 